\title{
A TEST OF THE EFFICIENCY OF THE FOREIGN EXCHANGE MARKET IN INDONESIA
}

\author{
Bernard Njindan Iyke ${ }^{1}$ \\ ${ }^{1}$ Centre for Financial Econometrics, Deakin Business School, Deakin University, Melbourne, \\ Australia, E-mail: bernard@deakin.edu.au
}

\begin{abstract}
We test whether the Indonesian foreign exchange market is efficient. Since empirical evidence has been inconclusive, we employ a new generalized autoregressive conditional heteroskedasticity-based unit root test to examine the Efficient Market Hypothesis (EMH). The advantages of this model are that it accommodates two endogenous structural breaks and heteroskedasticity. Tests that account for structural breaks reject the EMH in only $29 \%$ of cases. When we accommodate both structural breaks and heteroskedasticity, we find the EMH is rejected in $50 \%$ of cases. Finally, we examine the half-life of exchange rates and find that $71 \%$ of rates revert to equilibrium within a month.
\end{abstract}

Keywords: Foreign exchange market efficiency; Exchange rate; Unit root; Structural break; Half-life; Indonesia.

JEL Classifications: F31; G14; G15.

Article history:

Received : July 3, 2018

Revised : October 13, 2018

Accepted : December 11, 2018

Available online : January 31, 2019

https://doi.org/10.21098/bemp.v0i0.976 


\section{INTRODUCTION}

This paper tests whether the Indonesian Foreign Exchange (FX) market is efficient. The Efficient Market Hypothesis (EMH) argues that asset prices fully incorporate all information available. Given that prices fully reflect all information available, we cannot consistently gain from arbitrage on a risk-adjusted basis (Fama, 1965, 1970; Samuelson, 1965). Various studies have empirically examined the validity of the EMH, with mixed findings, leading to the proposition of flexible forms of the hypothesis (Fama, Fisher, Jensen, and Roll, 1969; Basu, 1977; Lo, 2004; Timmermann and Granger, 2004; Neely, Weller, and Ulrich, 2009; Narayan, Liu, and Westerlund, 2016). Although the hypothesis has been largely tested for stock markets, it has only recently gained significant attention in the FX markets. The evidence from the FX market literature is also mixed at best (Belaire-Franch and Opong, 2005; Giannellis and Papadopoulos, 2009; Al-Khazali, Pyun, and Kim, 2012; Katusiime, Shamsuddin, and Agbola, 2015).

Rejection of the EMH in the FX market implies that investors and/or traders can extract profit by exploiting pricing anomalies and that policies pursued under the assumption of an efficient market could be ineffective (Iyke, 2017). This would, in turn, require interventions by the relevant authorities to correct the market mispricing. Amidst the mixed evidence in the literature, we present a new test of the EMH using a Generalized Autoregressive Conditional Heteroskedasticity (GARCH)-based test for unit roots. The merit of this approach is that it accommodates two endogenous structural breaks and accounts for heteroskedasticity.

A common characteristic of financial variables (e.g. the exchange rate) is the presence of structural breaks, normally resulting from policy changes, changes to economic fundamentals, or sudden economic downturns (Nelson and Plosser, 1982; Perron, 1989). To address the structural break problem, various structural break unit root tests have been proposed in the literature. For instance, the seminal unit root test of Perron (1989) assumes that the structural breaks are exogenous (Zivot and Andrews, 2002). Subsequent studies addressing this problem (i.e. endogenizing the structural breaks) are, among others, those of Perron and Vogelsang (1992), Lumsdaine and Papell (1997), Lee and Strazicich (2003), and Narayan and Popp (2010; NP hereafter). Both exogenous and endogenous structural break tests make the rather restrictive assumption that the error term associated with the regression specification of the tests is independent and identically distributed, or i.i.d. (see also Ling and Li, 2003; Gospodinov, 2008; Narayan, Liu, and Westerlund, 2016). However, as demonstrated by Kim and Schmidt (1993), the unit root null is frequently rejected if the i.i.d. error assumption is violated.

Thus, our main contribution is to sidestep the i.i.d. error assumption by employing the recently developed test for unit roots of Narayan, Liu, and Westerlund (2016), which accommodates structural breaks endogenously and conditional heteroskedasticity. The literature corroborates that exchange rates are suitably characterized by GARCH(1,1) (Bollerslev, 1990; Alexander and Lazar, 2006; Rapach and Strauss, 2008). Thus, a test of FX market efficiency based on unit root techniques should be founded on the most appropriate exchange rate model. We claim that ours is founded on the most appropriate exchange rate model. 
Another contribution is that we examine the implications of the rejection or acceptance of the unit root null on the exchange rate's speed of adjustment to equilibrium. There is limited evidence in this area. We first show that the exchange rates of Indonesia exhibit up to two structural breaks. Then, we show that the error terms associated with the exchange rate models are far from i.i.d. From two tests of unit roots that account for structural breaks but not for heteroskedasticity, we find that the EMH is rejected for approximately $29 \%$ of the FX rates. We further explore the hypothesis by accounting for both structural breaks and heteroskedasticity. We find that the rejection rate of the EMH is quite a bit higher (50\%). We find the results to be generally robust using daily data. Moreover, we find that the FX market was less efficient pre-crisis when we split the sample into before and after the Asian Financial Crisis (AFC). Finally, we examine the adjustment of these exchange rates to equilibrium by computing their half-life. We find that approximately $71 \%$ of the exchange rates revert to their mean within one month following a deviation. This could mean that the FX market is efficient in the short term.

The AFC of 1997-1998 predominantly affected three countries: Indonesia, South Korea, and Thailand (Goldstein, 1998; Yamazawa, 1998). Notable during the crisis were the breakdown of the Thai baht and the sharp depreciation of the Indonesian rupiah and South Korea won (Goldstein, 1998; Yamazawa, 1998; Cerra and Saxena, 2002; Enoch, Frécaut, and Kovanen, 2003). As noted by Goldstein (1998), the AFC originated in Thailand, following a speculative attack on the Thai baht. ${ }^{2}$ Following the painful recovery of these countries from the crisis, there is recent evidence of a sharp depreciation in the Indonesian rupiah. On 3 September 2018, the rupiah recorded its lowest rate since the start of 2018 of 14.777 per dollar the lowest since the peak of the AFC - and 8.93\% depreciation (Tan, 2018). Amidst these currency events, our quest is to examine whether the rupiah FX market is efficient. The Indonesian FX market is particularly suitable for this study because bilateral rupiah exchange data are available, thus limiting the need to compute cross-rates.

We proceed in the remaining sections as follows. Section II reviews the literature on the EMH in the context of the FX market. Section III presents our data. Section IV outlines our empirical testing strategies. Section V presents the empirical results and the half-life analysis. Section VI provides concluding remarks.

\section{LITERATURE REVIEW}

The earliest conceptualization of the efficient market theory remains debatable (Jovanovic, 2012). However, formal theoretical exposition of the EMH is credited to Fama (1965). The EMH argues that asset prices fully incorporate all information available, thereby preventing market participants from consistently gaining from

\footnotetext{
2 Before the crisis, Thailand was practising a fixed exchange regime, with the baht pegged against the US dollar. The government failed to devalue the then-overvalued currency, in spite of the fact that the currency was not sufficiently backed by foreign reserves. Following market pressures, the baht was floated, leading to a massive depreciation, countrywide market reactions, and full-blown regional contagion (Goldstein, 1998).
} 
arbitrage on a risk-adjusted basis (Fama, 1965, 1970; Samuelson, 1965). The theory argues that asset returns tend to exhibit a random walk behavior (Fama, 1965; Malkiel, 2003). Hence, analysts (investors) cannot use fundamental or technical analysis to consistently generate risk-adjusted excess returns. Analysts can only outperform the market by buying riskier assets or using inside information (Fama and French, 2012).

The core assumption of the EMH is that economic agents are rational and thus maximize their utility following rational expectations (Fama, 1965). This means agents update their expectations, on the average, as soon as new relevant information arrives in the market. Specifically, the reactions of agents should be random and normally distributed to make market returns unexploitable after accounting for transaction costs (Fama, 1965). Depending on the completeness of information available to the agents, the EMH is grouped into three forms. Weak form efficiency argues that past asset prices or returns are poor predictors of future asset prices or returns (Fama, 1970). Semi-strong form efficiency argues that publicly available information is a poor predictor of future asset prices or returns (Fama, 1970). Strong-form efficiency argues that all information (public and private) is a poor predictor of future asset prices or returns (Fama, 1970).

The theory of EMH has been disputed by behavioural financial studies. These studies argue that asset markets are inefficient, owing to human errors, including but not limited to information bias, overconfidence, and overreaction (De Bondt and Thaler, 1985; Daniel and Titman, 1999; Jegadeesh and Titman, 2001; Malkiel, 2003; Shiller, 2003). These human-related errors (associated with information processing and judgement) yield an equilibrium wherein investors purchase growth stocks at the expense of value stocks. Hence, it is possible for investors who are less prone to these errors to outperform the market (Malkiel, 2003; Shiller, 2003).

The adaptive market hypothesis of Lo (2004) aims to blend the EMH and inefficiencies induced by human-related errors. The adaptive market hypothesis argues that markets are ecological systems where heterogeneous agents compete for profits. The profits are cyclical such that competition erodes extant profitable opportunities, while new ones come up. The presence of heterogeneous agents means that different trading strategies are available in the markets and that markets transition through varying degrees of efficiency and changes in the composition of agents (Lo, 2004). Consistent with this theory, Timmermann and Granger (2004) contend that there is no dominant trading strategy in the markets because, if there were, all agents would exploit it, thus driving profits to zero. Similarly, markets are enhanced over time because old, inefficient processes are supplanted by more efficient ones (Timmermann and Granger, 2004).

The results of empirical tests of the EMH have been largely mixed. What remains clear, though, is that the evidence generally rejects strong forms of the hypothesis (Basu, 1977; Rosenberg, Reid, and Lanstein, 1985; Fama and French, 1992). The consensus is that the assumptions underlying the strong forms of EMH are far from reality and that markets are likely exhibit weak form efficiency (Lo and MacKinlay, 1988; Timmermann and Granger, 2004). Generally, the weak form EMH implies that prices are unpredictable and excess returns are absent (see also 
Katusiime, Shamsuddin, and Agbola, 2015). Common tests of the weak form EMH are the variance ratio and unit root tests. In the following, we briefly review the variance ratio and unit root studies and then highlight our motivations.

Lo and MacKinlay (1988), using their variance ratio test, find that the weak form EMH is not supported by data. The variance ratio test of Lo and MacKinlay (1988) has motivated the development of other versions of the test, including the Wald joint variance ratio test (Richardson and Smith, 1991), the multiple variance ratio test (Chow and Denning, 1993), the automatic variance ratio (Choi, 1999), the sign- and rank-based variance ratio tests (Wright, 2000), the wild bootstrap variance ratio test (Kim, 2006), and the wild bootstrap automatic variance ratio test (Kim, 2009). Evidence from studies based on the variance ratio tests is mixed (Park and Irwin, 2007; Chiang, Lee, Su, and Tzou, 2010; Lim and Brooks, 2011; Charles, Darné, and Kim, 2012).

Similar to the variance ratio studies, unit root studies have examined the weak form EMH with varying degrees of success (Narayan, Liu, and Westerlund, 2016). These studies employ either time series techniques (Chaudhuri and $\mathrm{Wu}$, 2003) or panel data techniques (Balvers, Wu, and Gilliland, 2000). As documented by Narayan, Liu, and Westerlund (2016), the more recent unit root tests have documented evidence supporting the mean reversion of asset prices. This implies that it is possible to predict asset prices and thus the weak form EMH is rejected by recent studies.

We are motivated by three issues in the literature. The first is that variance ratio tests largely do not incorporate the structural breaks that often characterize asset prices. The unit root studies that handle this issue mainly assume that structural breaks are exogenous. We address this problem by allowing structural breaks to be endogenous.

The second issue is that studies have generally failed to incorporate the heteroskedastic behaviour of the variance of the error terms linked to the time evolution of asset prices. More technically, studies have made the rather restrictive assumption that the error term associated with the regression specification of the tests is i.i.d. (see also Ling and Li, 2003; Gospodinov, 2008; Narayan, Liu, and Westerlund, 2016). However, Kim and Schmidt (1993) show that the unit root null is frequently rejected if the i.i.d. error assumption is violated. Therefore, we test the weak form EMH using a unit root test that addresses this issue.

The third issue is that studies on EMH have broadly focused on stock markets. Recent studies have extended EMH tests to advanced economy FX markets (Neely, Weller, and Ulrich, 2009). Specifically, these studies show that simple trading rules are unprofitable in these markets (Olson, 2004; Park and Irwin, 2007; Harris and Yilmaz, 2009; Neely, Weller, and Ulrich, 2009; Serban, 2010). Using a battery of variance ratio tests, Katusiime, Shamsuddin, and Agbola (2015) find FX market inefficiency and a few short episodes of efficiency for a developing country. We add to these studies by analysing the FX market of an emerging market economy. Our extension permits us to explore how long it takes for exchange rates to revert to their means. 


\section{DATA}

We use monthly data on bilateral exchange rates between Indonesia and its top 15 major trading partners, namely, Australia, China, Germany, India, Japan, Malaysia, the Netherlands, Pakistan, the Philippines, Taiwan, Thailand, Singapore, South Korea, the United States, and Vietnam. ${ }^{3}$ We use monthly data because, when compared with daily or intra-day data, they are readily available for an extended period. Note that we replicate our main results using daily data. The common starting period for the daily data is 15 February 1979 and the monthly data start in January 1978. This is not necessarily a disadvantage of the daily data. The main issue is that daily observations are not available for five of the exchange rates from 20 May 2013 to 06 January 2015. ${ }^{4}$ We replace these missing observations using data from the respective trading partner's central bank and other sources. ${ }^{5}$ Due to the nature of the daily data compilation, we rely on monthly data throughout the analysis to ensure consistency and reliability.

We use the longest sample period available for each bilateral exchange rate when Indonesia had adopted a floating or managed float exchange rate regime. Under a floating or managed float regime, bilateral exchange rates are mainly determined by market conditions, which is necessary when testing FX market efficiency. By following the exchange rate regime classifications developed by Reinhart and Rogoff (2004), we see Indonesia has operated a managed float regime since 1978 (see also Ilzetzki, Reinhart, and Rogoff, 2017). Hence, our sample starts in January 1978 and ends in July 2018.

The bilateral exchange rates are for the rupiah per US dollar (IDR/USD), IDR/ CNY, IDR/EUR, the rupiah per Indian rupee (IDR/INR), the rupiah per yen (IDR/ JPY), the rupiah per South Korean won (IDR/KRW), IDR/MYD, the rupiah per Pakistan rupee (IDR/PKR), the rupiah per Philippine peso (IDR/PHP), IDR/SGD, the rupiah per Taiwan dollar (IDR/TWD), the rupiah per Thai baht (IDR/THB), and the rupiah per Vietnamese dong (IDR/VND). ${ }^{6}$ Data on all exchange rates are obtained from Global Financial Database.

3 These trading partners are determined from three sources: World's Top Exports (WTEx; see http://www. worldstopexports.com/indonesias-top-15-import-partners), World Integrated Trade Solution (WITS; see https:/wits.worldbank.org/CountryProfile/en/Country/IDN/Year/2016/TradeFlow/EXPIMP/Partner/bycountry\#), and the Observatory of Economic Complexity (OEC; available at https://atlas.media.mit.edu/ en/ profile/country/idn).

4 These exchange rates are for the rupiah per Australian dollar (IDR/AUD), the rupiah per yuan (IDR/ CNY), the rupiah per euro (IDR/EUR), the rupiah per Malaysian dollar (IDR/MYD), and the rupiah per Singapore dollar (IDR/SGD).

5 For instance, IDR/AUD rates are taken from https://www.rba.gov.au/statistics/historical-data. html\#exchange-rates and IDR/CNY rates are from https://www.exchangerates.org.uk/CNY-IDRexchange-rate-history-full.html. In some instances, daily observations are missing for particular dates. We fill such gaps using the arithmetic average of adjacent observations.

6 Data for the IDR/VND rate of exchange are not readily available. Therefore, we use the USD/VND and IDR/USD rates to calculate the cross-rates of the IDR/VND exchange rate (i.e. IDR/VND=(IDR/ $\left.\mathrm{USD})^{*}(\mathrm{USD} / \mathrm{VND})\right)$. The IDR/EUR rate is used as the exchange rate for Germany and the Netherlands. 
Figure 1 plots these exchange rates. The bilateral exchange rates of Indonesia mostly experienced depreciation during the sample period. The period between April 1997 and June 1998 shows the highest depreciation, marked greatly by the AFC of 1997-1998 and the Indonesian banking crisis (Cerra and Saxena, 2002; Enoch, Frécaut, and Kovanen, 2003). This period of sharp depreciation (upward movement in the exchange rate) was followed by a sharp appreciation (downward movement in the exchange rate) from July 1998 to December 1998, when the financial markets started recovering from the crisis (see Figure 1). The sharp appreciation of the rupiah against the Vietnamese dong between September 1983 to September 1985, immediately after the Vietnam War of 1955 to 1975, is also notable. In the post-AFC period, the rupiah was stable against two currencies, the Indian and Pakistani rupees (Figure 1). Sharp breaks in the exchange rates, particularly during the AFC, necessitate structural break frameworks to model them. We formally test for the presence of structural breaks in Section V.

\section{Figure 1. Bilateral Exchange Rates of Indonesia and Its Top 15 Trading Partners}

The figure shows the movements of the monthly raw bilateral exchange rates of Indonesia and its top 15 trading partners. The exchange rates are rupiah per US dollar (IDR/USD), rupiah per Australian dollar (IDR/AUD), rupiah per yuan (IDR/CNY), rupiah per euro (IDR/EUR), rupiah per Indian rupee (IDR/INR), rupiah per yen (IDR/JPY), rupiah per South Korean won (IDR/KRW), rupiah per Malaysian dollar (IDR/MYD), rupiah per Pakistan rupee (IDR/PKR), rupiah per Philippines peso (IDR/PHP), rupiah per Singapore dollar (IDR/SGD), rupiah per Taiwan dollar (IDR/TWD), rupiah per Thai baht (IDR/THB), and rupiah per Vietnam dong (IDR/VND). The sample period is from January 1978 to July 2018. This covers the managed float regime adopted by Indonesia (see Reinhart, and Rogoff, 2004). The maximum number of observations is 487 and the smallest is 468 .

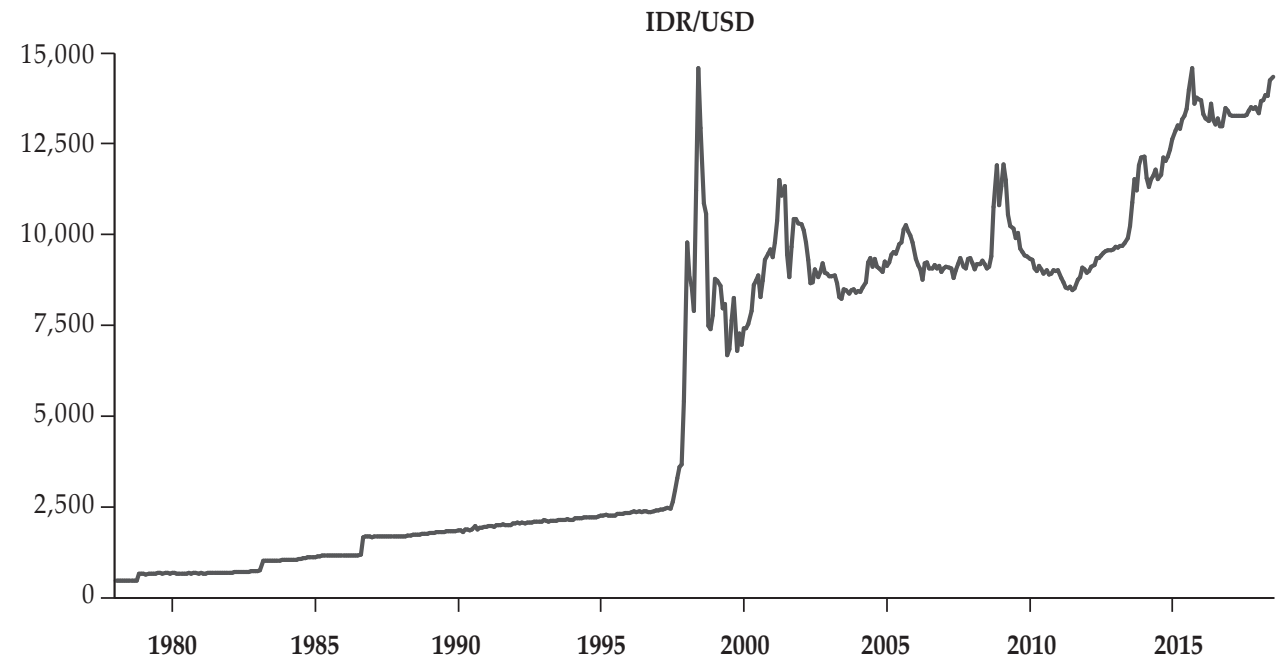



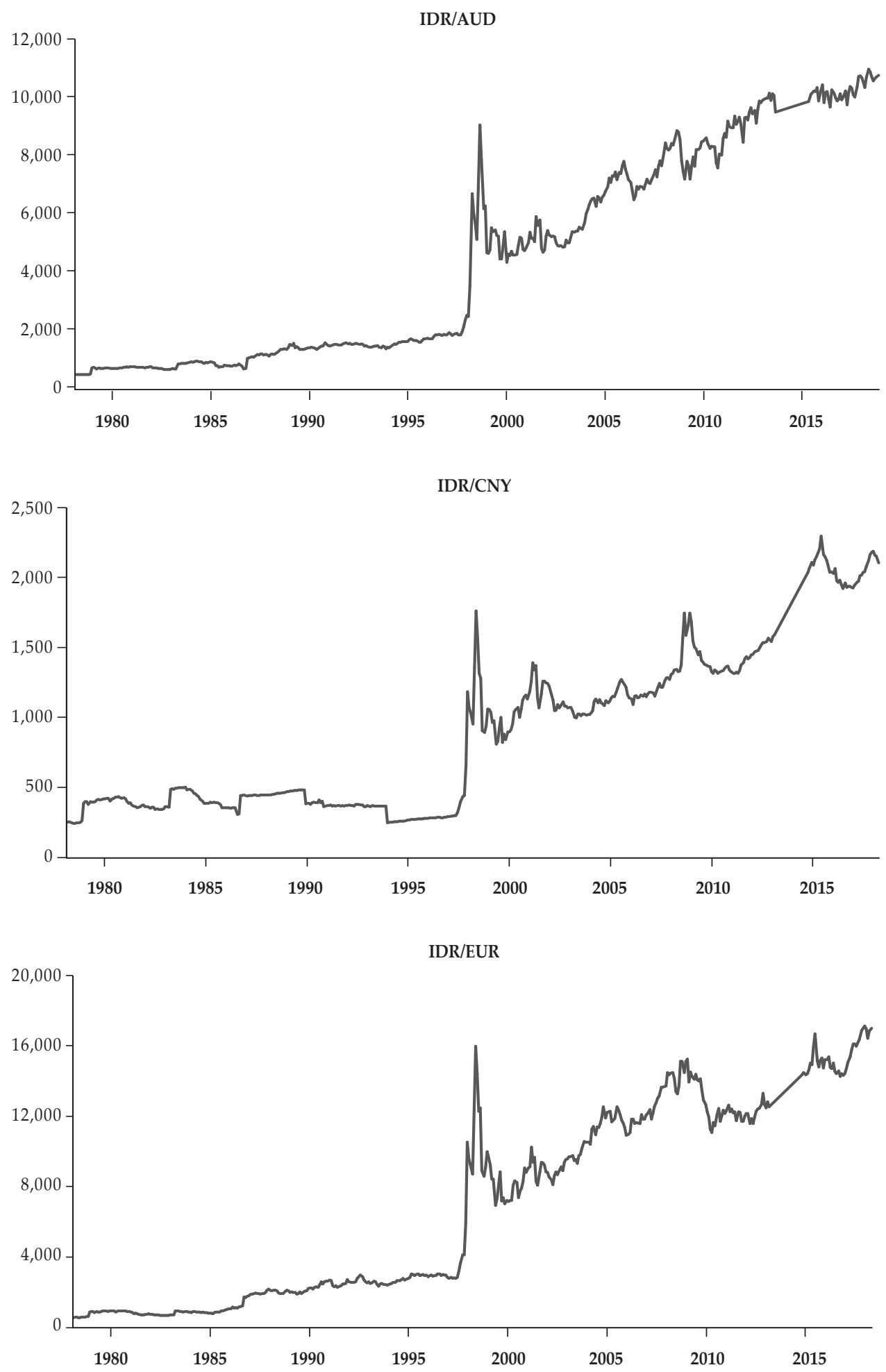

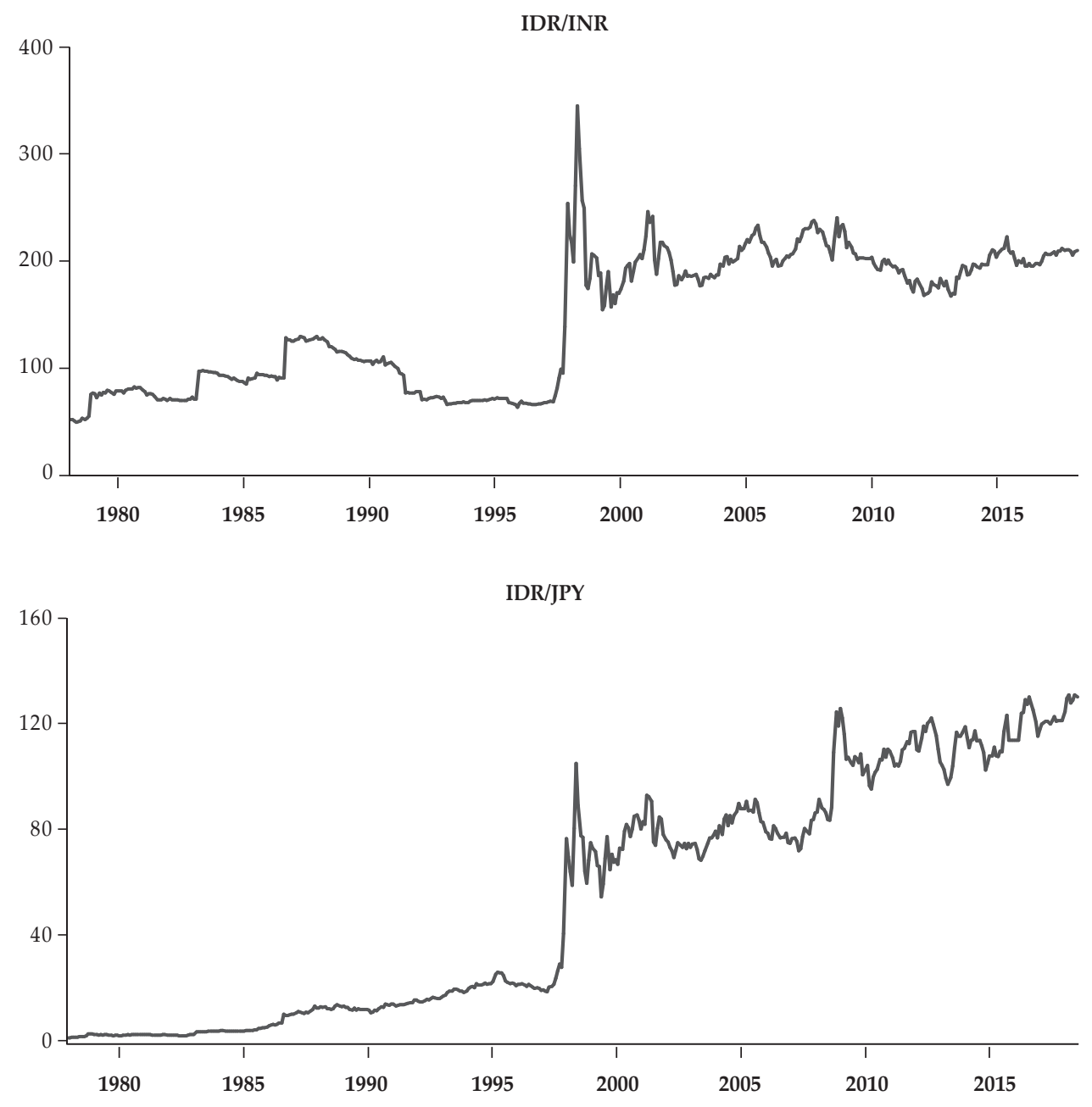

IDR/KRW

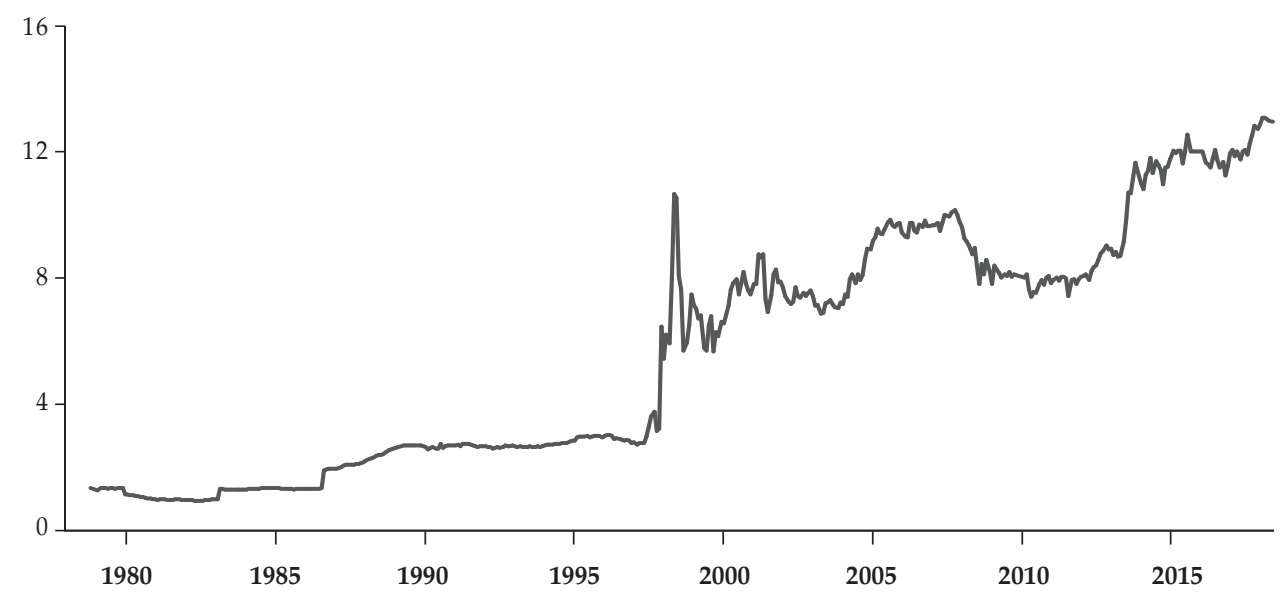


IDR/MYD

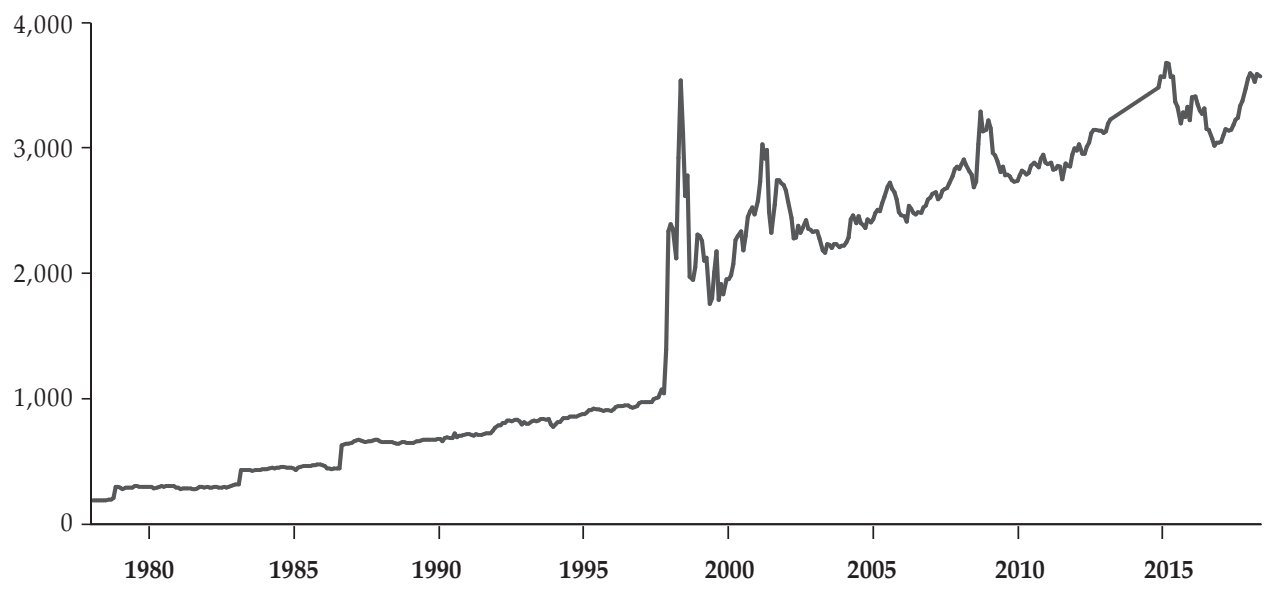

IDR/PKR
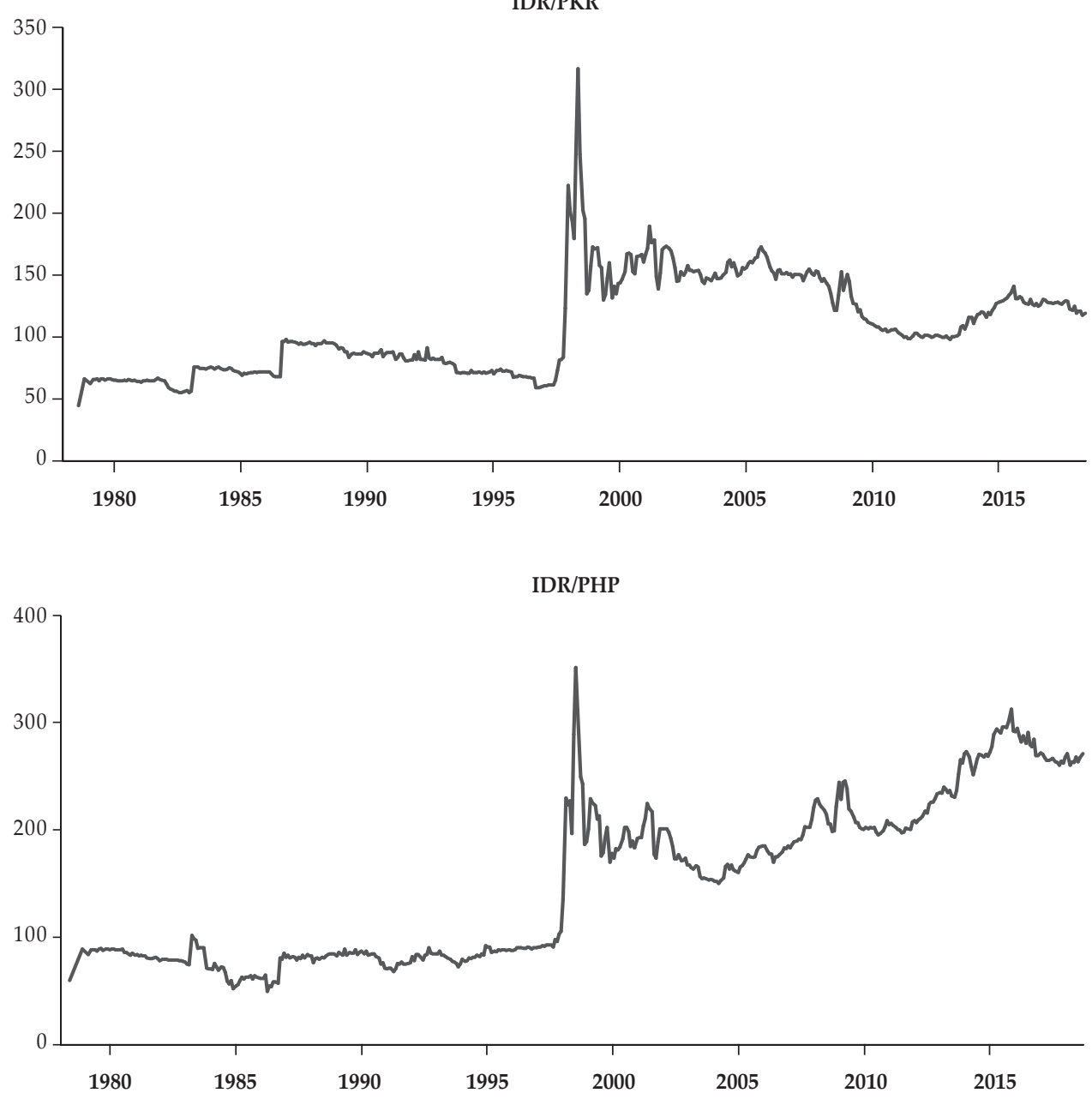
IDR/SGD

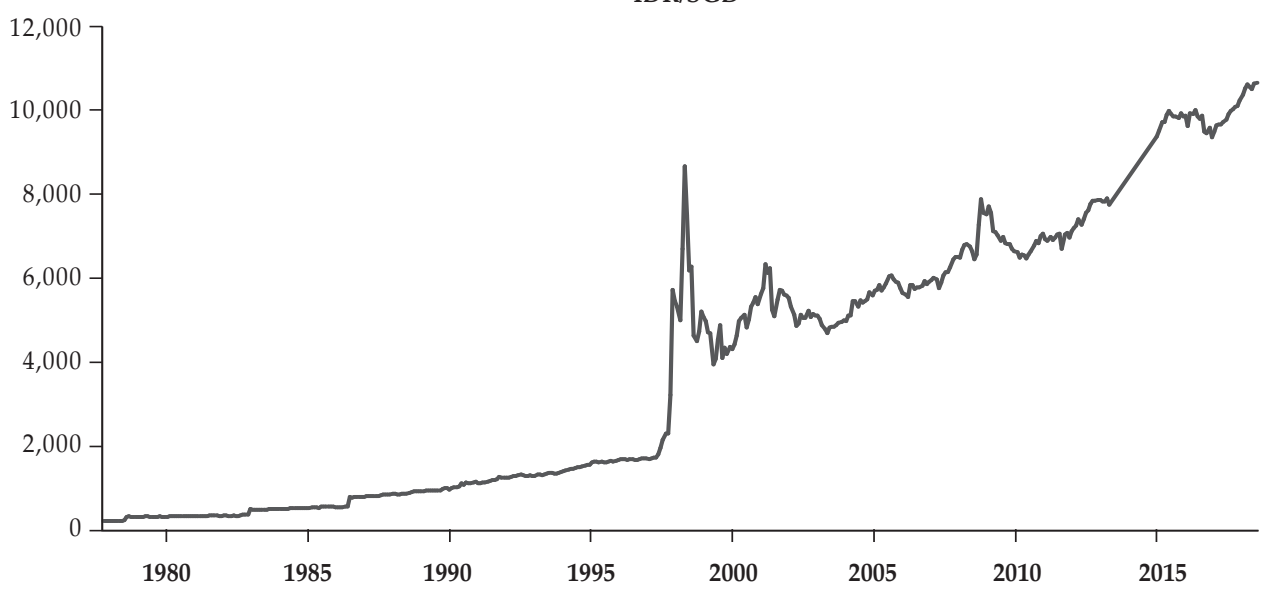

IDR/TWD

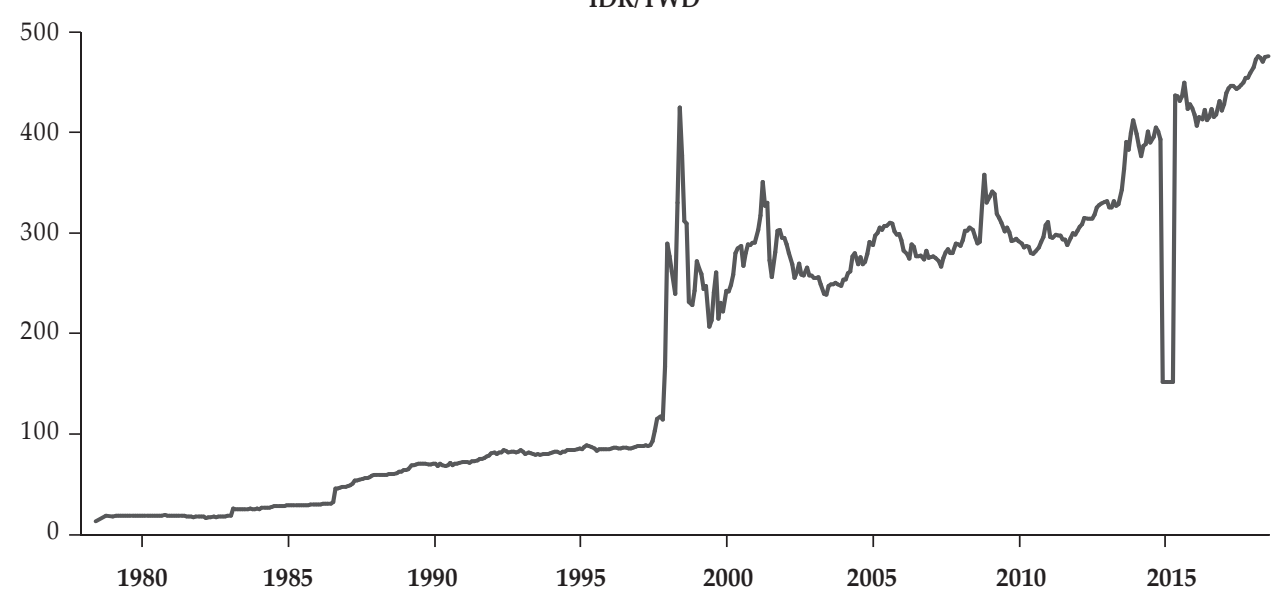

IDR/THB

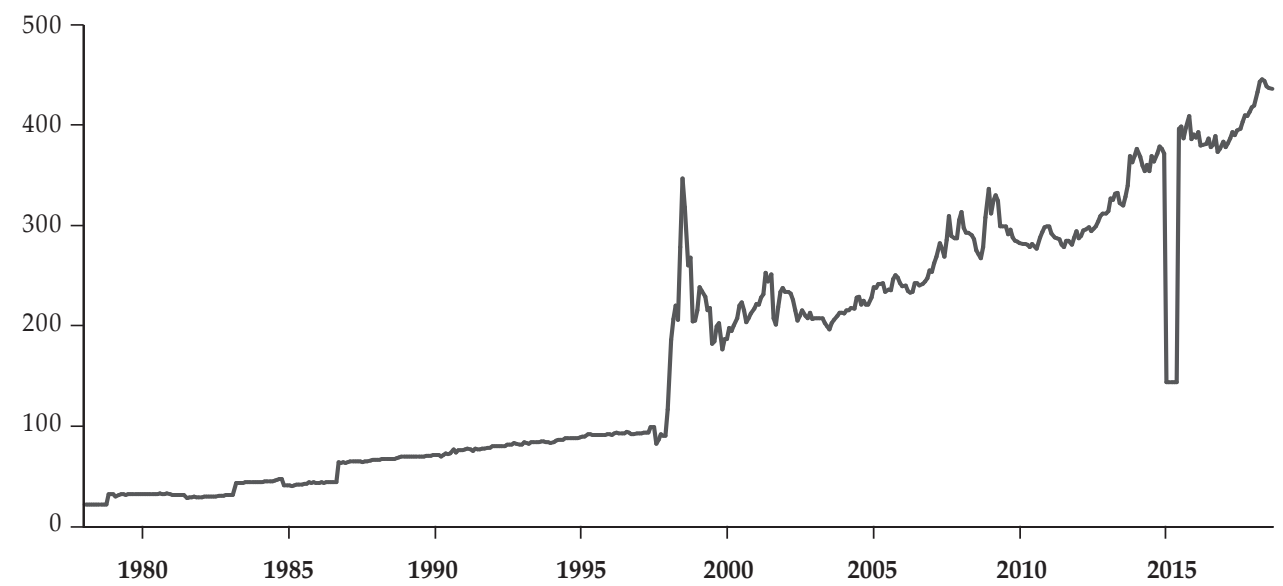


IDR/VND

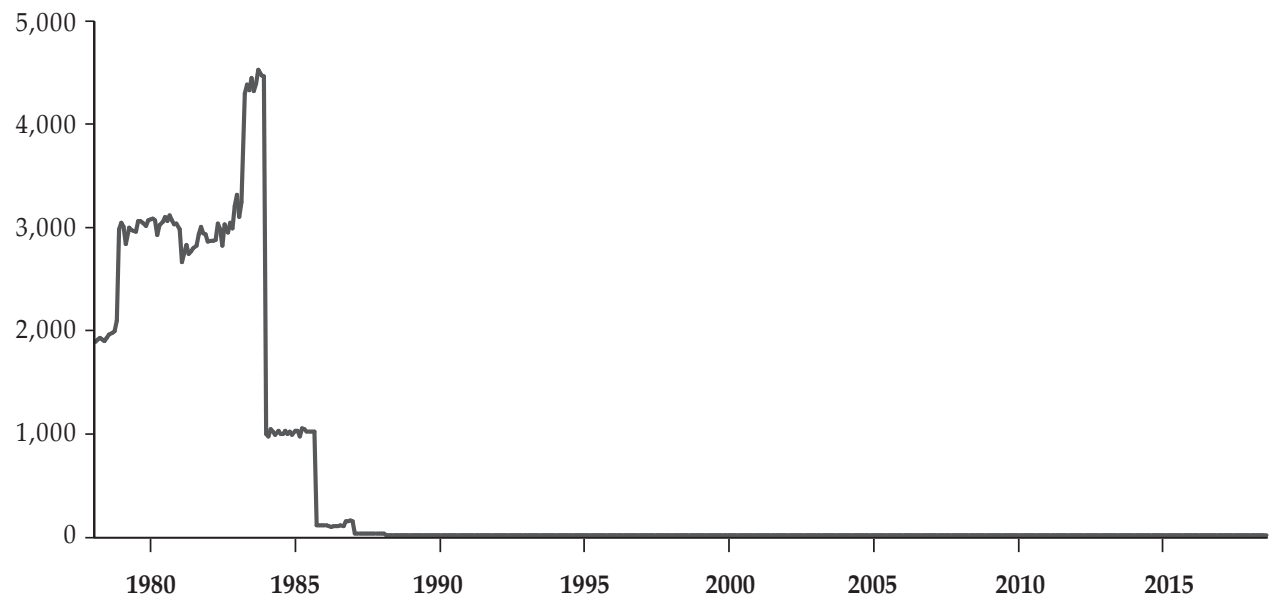

Table 1 shows the summary statistics. For the entire period (the sample period is from January 1978 to July 2018), the rupiah has done favourably, on the average, against the Korean won and the Japanese yen and poorly against the EUR and USD. Considering volatility (exchange rate risk), the most volatile exchange rate is that for IDR/EUR, while the least volatile is that for IDR/KRW. These quantities are represented by the standard deviations of 5461.760 and 3.811, respectively.

Table 1.

Summary Statistics

The table shows the summary statistics of the monthly raw bilateral exchange rates. The sample period is from January 1978 to July 2018. This covers the managed float regime adopted by Indonesia (see Reinhart, and Rogoff, 2004). The maximum number of observations is 487 and the smallest is 468 . Max, Min, SD, JB, and Obs. denote, respectively, maximum, minimum, standard deviation, Jarque-Bera statistic, and observations.

\begin{tabular}{lccccccccc}
\hline Variable & Mean & Max & Min & SD & Skewness & Kurtosis & JB & $p$-value & Obs. \\
\hline IDR/USD & 5895.477 & 14650 & 415 & 4561.386 & 0.211 & 1.475 & 50.798 & 0 & 487 \\
IDR/AUD & 4332.742 & 11012 & 469.192 & 3529.994 & 0.445 & 1.627 & 52.196 & 0 & 468 \\
IDR/CNY & 866.711 & 2306.4 & 239.331 & 573.029 & 0.707 & 2.364 & 46.914 & 0 & 468 \\
IDR/EUR & 6733.138 & 17192.3 & 508.329 & 5461.76 & 0.306 & 1.478 & 52.503 & 0 & 468 \\
IDR/INR & 144.328 & 346.336 & 48.368 & 62.128 & 0.052 & 1.605 & 39.714 & 0 & 487 \\
IDR/JPY & 54.161 & 131.56 & 1.718 & 44.886 & 0.207 & 1.413 & 54.554 & 0 & 487 \\
IDR/KRW & 5.679 & 13.147 & 0.887 & 3.811 & 0.249 & 1.625 & 42.319 & 0 & 475 \\
IDR/MYD & 1639.448 & 3694.1 & 173.553 & 1135.653 & 0.186 & 1.387 & 53.447 & 0 & 468 \\
IDR/PKR & 107.853 & 317.925 & 43.365 & 38.865 & 0.83 & 4.156 & 81.15 & 0 & 476 \\
IDR/PHP & 150.985 & 353.012 & 48.786 & 75.067 & 0.388 & 1.78 & 41.478 & 0 & 476 \\
IDR/SGD & 3734.478 & 10693.8 & 177.883 & 3224.134 & 0.493 & 1.914 & 41.938 & 0 & 468 \\
IDR/TWD & 189.476 & 478.29 & 11.512 & 142.059 & 0.252 & 1.664 & 40.473 & 0 & 476 \\
IDR/THB & 172.715 & 447.22 & 20.293 & 123.948 & 0.42 & 1.838 & 41.673 & 0 & 487 \\
IDR/VND & 488.958 & 4546.296 & 0.155 & 1096.872 & 2.117 & 6.112 & 560.318 & 0 & 487 \\
\hline
\end{tabular}


In addition, all the skewness statistics are positive and relatively far from zero. The implication is that bilateral exchange rates experiencing depreciation are likely going to depreciate and those that are presently stable will depreciate in the future. In terms of kurtosis, two exchange rates are leptokurtic: those for IDR/ VND and IDR/PKR. That is, they exhibit longer and fatter tails, with higher and sharper central peaks (Westerfield, 1977). The remainder are platykurtic, meaning that, when compared with normal distributions, their tails are shorter and thinner, with lower and broader central peaks. The Jarque-Bera test suggests that none of the exchange rates are normally distributed at conservative levels of significance. These results provide first evidence that the assumption pertaining to error terms being i.i.d. when the EMH is being tested could be misleading. We formally test this in Section V.

\section{GARCH UNIT ROOT TEST WITH TWO ENDOGENOUS STRUCTURAL BREAKS}

This section outlines the GARCH unit root test developed by Narayan, Liu, and Westerlund (2016), which is used to examine the EMH. The test incorporates structural breaks endogenously and accounts for heteroskedasticity in the error terms. Although several structural breaks are permissible, Narayan, Liu, and Westerlund (2016) found a maximum of two breaks to be sufficient. In our analysis, we formally verify this to ensure that our findings are not contaminated by wrong choices of structural breaks. That said, we employ a $\operatorname{GARCH}(1,1)$ unit root test that builds on the regression:

$$
y_{t}=\alpha_{0}+\pi y_{t-1}+D_{1} B_{1 t}+D_{2} B_{2 t}+\varepsilon_{t}
$$

where $\alpha_{0}$ is the intercept term, $y_{t-1}$ denotes the one-period lag of the dependent variable $y_{t^{\prime}} D_{1}$ and $D_{2}$ are the break dummy parameters, $B_{i t}=1$ for $t \geq T_{B i}$ and $B_{i t}=0$ otherwise; and the $T_{B i^{\prime}} \forall i=1,2$, are the structural break dates. The error term $\varepsilon_{t}$ is assumed, in most applications, to be i.i.d. Kim and Schmidt (1993) show that this assumption is deleterious if the time series is not drawn from a normal distribution. Narayan, Liu, and Westerlund (2016) address this problem by characterizing $\varepsilon_{t}$ as a first-order GARCH model (i.e. GARCH $(1,1)$ ) of the form

$$
\varepsilon_{t}=\eta_{t} \sqrt{h_{t}}, \quad h_{t}=\tau+\alpha \varepsilon_{t-1}^{2}+\beta h_{t-1}
$$

where $\tau, \alpha$, and $\beta$ are parameters of the model, $\tau>0, \alpha \geq 0$, and $\beta \geq 0$, and $\eta_{t}$ is assumed to be i.i.d. (i.e. it has a zero mean and unit variance).

Equation (2) can be estimated using various approaches. For example, Ling, $\mathrm{Li}$, and McAleer (2003) show that it can be estimated in a two-step process. In the first step, $\pi$ is estimated using least squares. Then we generate a series of artificial values for the residual, $\varepsilon_{t}$. In the second step, we estimate the coefficients of the variance equation $(\tau, \alpha, \beta)$ using the generated values of $\varepsilon_{t}$. An alternative approach proposed by Seo (1999) is built on joint maximum likelihood estimation. Specifically, the unit root null (i.e. $H_{0:} \pi=1$ ) is tested using the maximum likelihood t-ratio for $\pi$. We follow Narayan, Liu, and Westerlund (2016) and used the second approach in our analysis, as follows. Because the break date is unknown, we 
substitute $T_{B i}(i=1,2)$ with their estimates, $T_{B i}$. Estimates of $T_{B i}$ are carried out sequentially. To obtain the first break date, we use the maximum absolute $t$-value of the break dummy coefficient $D_{1}, t_{\widehat{D}_{1}}$. That is,

$$
\widehat{T}_{B 1}=\underset{\widehat{T}_{B 1}}{\operatorname{argmax}}\left|t_{\widehat{D}_{1}}\left(T_{B 1}\right)\right|
$$

Then, using the first break estimate, $\widehat{T}_{B 1}$, we proceed to obtain the second break date, $\widehat{T}_{B 2}$ :

$$
\widehat{T}_{B 2}=\underset{\widehat{T}_{B 2}}{\operatorname{argmax}}\left|t_{\widehat{D}_{2}}\left(\widehat{T}_{B 1}, T_{B 2}\right)\right|
$$

In a simulation experiment, Narayan, Liu, and Westerlund (2016) show the following. The critical values underlying the unit root null changes less with changing GARCH parameters, irrespective of the combination of structural breaks. As the sample size increases, the finite sample critical values converge to a classic Dickey-Fuller distribution. The unit root test is oversized in small samples but performs well in large samples. Additionally, the empirical size of the test is correctly sized in large samples, regardless of the GARCH orders and break parameters. Our sample is quite large and thus the test is applicable. Finally, if structural breaks and GARCH effects are present, the test is nearly five times more powerful than the standard augmented Dickey-Fuller test.

\section{EMPIRICAL ANALYSIS}

We begin our analysis by considering a key question. How many structural breaks should we consider when testing FX market efficiency? Without knowing the number of structural breaks to be modelled when testing the foreign market efficiency, we could provide evidence based on false models. Narayan, Liu, and Westerlund (2016) find that two structural breaks are sufficient when testing the efficiency of stock returns. However, this might not apply to other markets. To address this question, we utilize Bai and Perron's $(1998,2003)$ test.

We use Bai and Perron's $(1998,2003)$ double maximum tests and analyse the null of no structural breaks against the alternative of at least one to $m$ structural breaks. There are two statistics for the double maximum tests. The first test generates the unweighted double maximum (UDmax) statistic, while the second test generates the weighted double maximum (WDmax) statistic (Bai and Perron, 1998). The structural breaks obtained using these tests are shown in Table 2. We find that 13 of the 14 bilateral exchange rates have at most two structural breaks and one has a single structural break. The AFC and the Indonesian banking crisis (of 1997-1998) are correctly identified by the tests in most of the cases. This evidence suggests that our analysis should consider at most two structural breaks. 
Table 2.

Test for Structural Breaks in the Exchange Rates

The table shows the test for structural breaks in the bilateral exchange rates using the Bai and Perron (1998, 2003) procedure. This procedure allows for multiple structural breaks in a series to be tested. We used the double maximum tests. The first test generates the unweighted double maximum (UDmax) statistic, which is the maximum value of the F-statistic. The second generates the weighted double maximum (WDmax) statistic, which takes the weights of the individual statistics to equalize the $p$-values across the values of structural breaks (Bai and Perron, 1998). In all cases, the exchange rates are in natural logarithm. The sample period is from January 1978 to July 2018.

\begin{tabular}{lcccc}
\hline & UDmax & & \multicolumn{2}{c}{ WDmax } \\
\hline Variable & Break one & Break two & Break one & Break two \\
\hline IDR/USD & $1992 \mathrm{M} 02$ & $1998 \mathrm{M} 02$ & $1992 \mathrm{M} 02$ & $1998 \mathrm{M} 02$ \\
IDR/AUD & $1997 \mathrm{M} 12$ & $2003 \mathrm{M} 09$ & $1997 \mathrm{M} 12$ & $2003 \mathrm{M} 09$ \\
IDR/CNY & $1997 \mathrm{M} 12$ & $2003 \mathrm{M} 09$ & $1997 \mathrm{M} 12$ & $2003 \mathrm{M} 09$ \\
IDR/EUR & $1997 \mathrm{M} 12$ & $2003 \mathrm{M} 09$ & $1997 \mathrm{M} 12$ & $2003 \mathrm{M} 09$ \\
IDR/INR & $1997 \mathrm{M} 12$ & --- & $1992 \mathrm{M} 02$ & $1998 \mathrm{M} 02$ \\
IDR/JPY & $1997 \mathrm{M} 12$ & $2004 \mathrm{M} 05$ & $1997 \mathrm{M} 12$ & $2004 \mathrm{M} 05$ \\
IDR/KRW & $1998 \mathrm{M} 01$ & $2004 \mathrm{M} 05$ & $1998 \mathrm{M} 01$ & $2004 \mathrm{M} 05$ \\
IDR/MYD & $1997 \mathrm{M} 12$ & $2003 \mathrm{M} 09$ & $1997 \mathrm{M} 12$ & $2003 \mathrm{M} 09$ \\
IDR/PKR & $1997 \mathrm{M} 12$ & $2003 \mathrm{M} 10$ & $1997 \mathrm{M} 12$ & $2003 \mathrm{M} 10$ \\
IDR/PHP & $1997 \mathrm{M} 12$ & $2003 \mathrm{M} 10$ & $1997 \mathrm{M} 12$ & $2003 \mathrm{M} 10$ \\
IDR/SGD & $1997 \mathrm{M} 12$ & $2003 \mathrm{M} 09$ & $1997 \mathrm{M} 12$ & $2003 \mathrm{M} 09$ \\
IDR/TWD & $1997 \mathrm{M} 12$ & --- & $1997 \mathrm{M} 12$ & $2012 \mathrm{M} 08$ \\
IDR/THB & $1997 \mathrm{M} 12$ & $2006 \mathrm{M} 10$ & $1997 \mathrm{M} 12$ & $2006 \mathrm{M} 10$ \\
IDR/VND & $1985 \mathrm{M} 09$ & --- & $1985 \mathrm{M} 09$ & -- \\
\hline
\end{tabular}

We proceed to examine the EMH using unit roots tests that accommodate two structural breaks. Specifically, we use the test of Caner and Hansen (2001; CH hereafter) for threshold effects and unit roots and the NP tests for two endogenous structural breaks. Table 3 shows the results. The $\mathrm{CH}$ test results report the Wald statistic $\left(W_{\mathrm{T}}\right)$ for threshold effects and the one-sided threshold unit root test statistic $\left(R_{1, T}\right)$. The null of no threshold effects is rejected for seven of the 14 exchange rates $(50 \%)$. Therefore, we reject the linear autoregressive model and accept the threshold autoregressive model. The unit root null is rejected for only four of the 14 exchange rates $(28.57 \%)$. The $\mathrm{CH}$ test therefore lends credence to the EMH for $71.43 \%$ of the exchange rates. 
Table 3.

\section{Structural Break Unit Root Tests of EMH}

The table shows the results based on the structural break unit root tests of FX market efficiency. For the Caner and Hansen (2001) test, we report their Wald statistic $\left(W_{T}\right)$ and the one-sided threshold unit root test statistic $\left(R_{1, T}\right)$ for the chosen delay parameter between 1 and 6, which are compared to the bootstrap $p$-values. The bootstrap $p$-values are generated using 1000 replications. For the Narayan and Popp (2010) test, we report the M1 and M2 statistics and compare them to the critical values tabulated in their paper. Lags for the Narayan and Popp (2010) test are based on the procedure suggested by Hall (1994). Caner and Hansen (2001) test accounts for threshold effects and unit roots, while Narayan and Popp (2010) test accounts for two endogenous structural breaks. In both cases, we include only the intercept. Note that TB1, TB2, and k denote, respectively, the first and second structural break dates, and optimal lag selected. In all cases, the exchange rates are in natural logarithm. The sample period is from January 1978 to July 2018.

\begin{tabular}{lcccc}
\hline \multicolumn{5}{c}{ Caner-Hansen (2001) test } \\
\hline Variable & $\mathbf{W}_{\mathrm{T}}$ & $p$-value (lag) & $\mathbf{R}_{1, \mathrm{~T}}$ & $p$-value \\
\hline IDR/USD & 50.462 & $0.001(3)$ & 13.098 & 0.068 \\
IDR/AUD & 7.511 & $0.431(1)$ & 5.7 & 0.46 \\
IDR/CNY & 3.995 & $0.800(1)$ & 7.22 & 0.37 \\
IDR/EUR & 3.889 & $0.846(3)$ & 3.85 & 0.6 \\
IDR/INR & 36.931 & $0.004(3)$ & 15.309 & 0.059 \\
IDR/JPY & 24.375 & $0.017(3)$ & 14.034 & 0.036 \\
IDR/KRW & 28.831 & $0.011(2)$ & 13.921 & 0.061 \\
IDR/MYD & 6.999 & $0.433(3)$ & 5.48 & 0.48 \\
IDR/PKR & 24.255 & $0.013(3)$ & 4.3 & 0.53 \\
IDR/PHP & 30.434 & $0.005(2)$ & 5.56 & 0.39 \\
IDR/SGD & 5.109 & $0.647(3)$ & 7.13 & 0.37 \\
IDR/TWD & 16.445 & $0.116(2)$ & 2.1 & 0.76 \\
IDR/THB & 7.225 & $0.516(1)$ & 5.27 & 0.47 \\
IDR/VND & 22.723 & $0.075(1)$ & 17.917 & 0.106 \\
\hline
\end{tabular}

\begin{tabular}{|c|c|c|c|c|c|c|c|c|c|c|}
\hline \multicolumn{11}{|c|}{ Narayan-Popp (2010) test } \\
\hline \multirow[b]{2}{*}{ Variable } & \multicolumn{5}{|c|}{ M1 } & \multicolumn{5}{|c|}{ M2 } \\
\hline & $\begin{array}{c}\text { Test } \\
\text { statistic }\end{array}$ & TB1 & TB2 & k & Status & $\begin{array}{c}\text { Test } \\
\text { statistic }\end{array}$ & TB1 & TB2 & k & Status \\
\hline IDR/USD & -2.722 & $1997-12$ & 1998-09 & 5 & $\mathrm{I}(1)$ & -2.628 & $1997-12$ & 1998-09 & 5 & $\mathrm{I}(1)$ \\
\hline IDR/AUD & -3.942 & $1997-12$ & 1998-04 & 0 & $\mathrm{I}(0)$ & -4.076 & $1997-12$ & 1998-06 & 0 & $\mathrm{I}(1)$ \\
\hline IDR/CNY & -3.675 & $1997-12$ & 1998-04 & 0 & $\mathrm{I}(1)$ & -4.085 & $1997-12$ & 1998-06 & 0 & $\mathrm{I}(1)$ \\
\hline IDR/EUR & -3.687 & $1997-12$ & 1998-04 & 0 & $\mathrm{I}(1)$ & -3.789 & $1997-12$ & 1998-06 & 0 & $\mathrm{I}(1)$ \\
\hline IDR/INR & -3.647 & $1997-12$ & 1998-09 & 5 & $\mathrm{I}(1)$ & -4.122 & $1997-12$ & 1998-06 & 5 & $\mathrm{I}(1)$ \\
\hline IDR/JPY & -3.416 & $1997-12$ & 1998-05 & 5 & $\mathrm{I}(1)$ & -4.485 & $1997-12$ & 1998-06 & 5 & $\mathrm{I}(0)$ \\
\hline IDR/KRW & -1.511 & $1997-12$ & 1998-05 & 5 & $\mathrm{I}(1)$ & -3.081 & $1997-12$ & 1998-07 & 4 & $\mathrm{I}(1)$ \\
\hline IDR/MYD & -4.267 & $1997-12$ & 1998-09 & 0 & $\mathrm{I}(0)$ & -4.299 & $1997-12$ & 1998-06 & 0 & $\mathrm{I}(1)$ \\
\hline IDR/PKR & -5.581 & $1997-12$ & 1998-04 & 4 & $\mathrm{I}(0)$ & -5.889 & $1997-12$ & 1998-06 & 5 & $\mathrm{I}(0)$ \\
\hline IDR/PHP & -3.834 & $1997-12$ & 1998-04 & 5 & $\mathrm{I}(0)$ & -4.9 & $1997-12$ & 1998-04 & 5 & $\mathrm{I}(0)$ \\
\hline IDR/SGD & -3.765 & $1997-12$ & 1998-04 & 0 & $\mathrm{I}(1)$ & -3.914 & $1997-12$ & 1998-06 & 0 & $\mathrm{I}(1)$ \\
\hline IDR/TWD & -4.661 & $1997-12$ & 1998-05 & 5 & $\mathrm{I}(0)$ & -5.306 & $1997-12$ & 1998-05 & 5 & $\mathrm{I}(0)$ \\
\hline IDR/THB & -3.898 & $1997-12$ & 1998-05 & 5 & $\mathrm{I}(0)$ & -5.933 & $1997-12$ & 1998-05 & 5 & $\mathrm{I}(0)$ \\
\hline IDR/VND & -2.587 & 1986-02 & $1986-12$ & 0 & $\mathrm{I}(1)$ & -5.009 & $1990-10$ & 1991-01 & 0 & $\mathrm{I}(0)$ \\
\hline
\end{tabular}


We now consider the NP results in the lower panel of Table 3. The NP test accommodates two endogenous structural breaks and therefore takes care of the two structural breaks identified in Table 2 . The NP test correctly identifies the AFC and the Indonesian banking crisis of 1997-1998. Both the M1 and M2 results show that the unit root null is rejected for six of the 14 exchange rates $(42.86 \%)$. The two results are conclusive for the unit root null rejection in four out 14 (28.57\%). Therefore, like the $\mathrm{CH}$ test, the NP test results supports the EMH for approximately $71.43 \%$ of the exchange rates.

The main limitation of the above results is that they assume i.i.d. errors in the underlying models of the bilateral exchange rates. Are these results reliable when the i.i.d. error assumption is violated? We address this question by formally establishing that the errors are anything but i.i.d. Specifically, we use the BreuschPagan-Godfrey and autoregressive conditional heteroskedasticity tests to examine whether the variances of the error terms are homoscedastic. Table 4 shows the results. Both tests largely reject the null hypothesis of no heteroskedasticity or autoregressive conditional heteroskedasticity effects. Hence, it is safe to conclude that the results in Table 3 are not reliable. A key contribution of the paper is to address this problem using a unit root test that accounts for heteroskedasticity.

Table 4.

Tests for Heteroskedasticity

The table reports tests for heteroskedasticity in the errors of the bilateral exchange rates. The tests are the BreuschPagan-Godfrey and the autoregressive conditional heteroskedasticity $(\mathrm{ARCH})$ tests, with associated Lagrange Multiplier (LM) statistics. We filtered each of the exchange rates using an AR(12) model. We then tested the generated residuals for heteroskedasticity or ARCH effects. Specifically, we test the null hypothesis of no heteroskedasticity or $\mathrm{ARCH}$ effects. In all cases, the exchange rates are in natural logarithm. The sample period is from January 1978 to July 2018.

\begin{tabular}{lcccc}
\hline & \multicolumn{2}{c}{ ARCH } & \multicolumn{2}{c}{ Breusch-Pagan-Godfrey } \\
\hline Exchange Rate & LM Statistic & $p$-value & LM Statistic & $p$-value \\
\hline IDR/USD & 6.614 & 0 & 39.402 & 0 \\
IDR/AUD & 48.471 & 0 & 53.679 & 0 \\
IDR/CNY & 37.654 & 0 & 30.184 & 0.003 \\
IDR/EUR & 60.841 & 0 & 39.696 & 0 \\
IDR/INR & 52.958 & 0 & 50.103 & 0 \\
IDR/JPY & 43.917 & 0 & 42.385 & 0 \\
IDR/KRW & 53.577 & 0 & 66.237 & 0 \\
IDR/MYD & 51.197 & 0 & 32.143 & 0.001 \\
IDR/PKR & 74.706 & 0 & 70.788 & 0 \\
IDR/PHP & 90.256 & 0 & 41.83 & 0 \\
IDR/SGD & 49.878 & 0 & 43.273 & 0 \\
IDR/TWD & 57.131 & 0 & 28.396 & 0.005 \\
IDR/THB & 53.067 & 0 & 22.849 & 0.029 \\
IDR/VND & 6.569 & 0.885 & 7.439 & 0.827 \\
\hline
\end{tabular}


We apply the GARCH $(1,1)$ unit root test to the bilateral exchange rates and report the statistics in Table 5. The unit root null is rejected for seven of the 14 exchange rates (50\%). This implies that the EMH is supported in $50 \%$ of the cases, representing a reduction in support of the hypothesis of $21.43 \%$ when compared with the $\mathrm{CH}$ and NP results. Thus, the heteroskedasticity in the errors of the exchange rates series appears to influence the unit root-based EMH tests. Our results specifically show that it might be possible to predict the bilateral exchange rates of the rupiah versus the Austrian dollar, euro, Korean won, Pakistani rupee, Philippine peso, Taiwan dollar, and Thai baht. Our finding that FX markets could be efficient is consistent with the results of Katusiime, Shamsuddin, and Agbola (2015), who find intermittent FX market efficiency, but contradicts Neely, Weller, and Ulrich (2009), who find no support for the EMH.

\section{Table 5.}

\section{GARCH-based Unit Root Test for EMH}

The table shows the results using the GARCH-based endogenous structural break unit root tests of FX market efficiency. The results are based on Eq. (1). The two structural breaks denoted by TB1 and TB2 are reported together with the t-test statistic used to test the null hypothesis of a unit root. Specifically, we test the null hypothesis of no unit roots. In all cases, the exchange rates are in natural logarithm. The sample period is from January 1978 to July 2018. Finally, ${ }^{* *}$ denotes significance at the $5 \%$ level.

\begin{tabular}{lccc}
\hline Exchange Rate & $t$-statistic & TB1 & TB2 \\
\hline IDR/USD & -0.124 & $1988 \mathrm{M} 01$ & $2014 \mathrm{M} 05$ \\
IDR/AUD & $-9.027^{* *}$ & $1996 \mathrm{M} 02$ & $2000 \mathrm{M} 03$ \\
IDR/CNY & -1.393 & $1992 \mathrm{M} 02$ & $1994 \mathrm{M} 02$ \\
IDR/EUR & $-10.490^{* *}$ & $1985 \mathrm{M} 12$ & $1998 \mathrm{M} 03$ \\
IDR/INR & -1.628 & $1981 \mathrm{M} 12$ & $1988 \mathrm{M} 01$ \\
IDR/JPY & -1.479 & $1979 \mathrm{M} 11$ & $1990 \mathrm{M} 01$ \\
IDR/KRW & $-11.437^{* *}$ & $1983 \mathrm{M} 12$ & $1998 \mathrm{M} 03$ \\
IDR/MYD & -1.285 & $1985 \mathrm{M} 12$ & $1990 \mathrm{M} 01$ \\
IDR/PKR & $-8.674^{* *}$ & $1981 \mathrm{M} 12$ & $2008 \mathrm{M} 04$ \\
IDR/PHP & $-7.439^{* *}$ & $1981 \mathrm{M} 12$ & $1998 \mathrm{M} 03$ \\
IDR/SGD & -0.054 & $1998 \mathrm{M} 03$ & $1998 \mathrm{M} 03$ \\
IDR/TWD & $-17.809^{* *}$ & $1981 \mathrm{M} 12$ & $2016 \mathrm{M} 06$ \\
IDR/THB & $-14.866^{* *}$ & $1985 \mathrm{M} 12$ & $1998 \mathrm{M} 03$ \\
IDR/VND & -1.974 & $1981 \mathrm{M} 12$ & $1990 \mathrm{M} 01$ \\
\hline
\end{tabular}

As a sensitivity analysis, we compile daily data for the period from 15 February 1979 to 31 July 2018 and reapply the GARCH $(1,1)$ unit root test to the bilateral exchange rates. These results are shown in Table 6 . The results are broadly similar to those in Table 5, except for two exchange rates (IDR/EUR and IDR/PHP), where the test fails to reject the unit root null. The EMH is supported in $64.43 \%$ of cases, which is again considerably lower than in the $\mathrm{CH}$ and NP results. 
Table 6.

\section{GARCH-based Unit Root Test for EMH Using Daily Data}

The table shows the results using the GARCH-based endogenous structural break unit root tests of FX market efficiency. The results are based on Eq. (1) and daily data. The two structural breaks denoted by TB1 and TB2 are reported together with the t-test statistic used to test the null hypothesis of a unit root. Specifically, we test the null hypothesis of no unit roots. In all cases, the exchange rates are in natural logarithm. The sample period is 15/2/1979 to $31 / 7 / 2018$. Finally, ${ }^{* * *}$ and ${ }^{* *}$ denote statistical significance at the $1 \%$ and $5 \%$ levels, respectively.

\begin{tabular}{lccc}
\hline Exchange Rate & $t$-statistic & TB1 & TB2 \\
\hline IDR/USD & -2.796 & $9 / 8 / 2016$ & $9 / 8 / 2016$ \\
IDR/AUD & $-12.249^{* *}$ & $6 / 11 / 1998$ & $7 / 10 / 2004$ \\
IDR/CNY & -2.075 & $7 / 10 / 2004$ & $29 / 8 / 2012$ \\
IDR/EUR & -1.506 & $28 / 11 / 1994$ & $28 / 11 / 1994$ \\
IDR/INR & -1.36 & $15 / 1 / 1985$ & $9 / 8 / 2016$ \\
IDR/JPY & -0.433 & $8 / 9 / 2010$ & $29 / 8 / 2012$ \\
IDR/KRW & $-4.281^{*}$ & $7 / 12 / 1992$ & $28 / 11 / 1994$ \\
IDR/MYD & -0.816 & $17 / 12 / 1990$ & $6 / 11 / 1998$ \\
IDR/PKR & $-12.377^{* *}$ & $9 / 8 / 2016$ & $9 / 8 / 2016$ \\
IDR/PHP & -1.407 & $27 / 10 / 2000$ & $17 / 10 / 2002$ \\
IDR/SGD & -0.551 & $15 / 1 / 1985$ & $6 / 1 / 1987$ \\
IDR/TWD & $-5.244^{* *}$ & $15 / 1 / 1985$ & $17 / 10 / 2002$ \\
IDR/THB & $-41.933^{* * *}$ & $27 / 10 / 2000$ & $29 / 8 / 2012$ \\
IDR/VND & -1.984 & $9 / 8 / 2016$ & $9 / 8 / 2016$ \\
\hline
\end{tabular}

We perform further sensitivity analysis by splitting the sample into periods before the AFC (Indonesian banking crisis) and after the AFC (Indonesian banking crisis). Table 7 shows the results. The unit root null is rejected for 12 of the 14 exchange rates $(85.7 \%)$ pre-AFC and seven of the $14(50 \%)$ post-AFC. The results suggest that the EMH is supported in $14.3 \%$ of cases before the crisis and in $50 \%$ of cases after the crisis. In other words, the FX market was less efficient before the crisis. 
Table 7.

\section{GARCH-based Unit Root Test for EMH Pre- and Post-AFC}

The table shows the results using the GARCH-based endogenous structural break unit root tests of FX market efficiency pre- and post-AFC. The results are based on Eq. (1). The two structural breaks denoted by TB1 and TB2 are reported together with the t-test statistic used to test the null hypothesis of a unit root. Specifically, we test the null hypothesis of no unit roots. In all cases, the exchange rates are in natural logarithm. The sample period is split into two: before AFC i.e. from January 1978 to March 1997, and after AFC i.e. from July 1998 to July 2018. Finally, ${ }^{*}$ and ** denote statistical significance at the $10 \%$ and $5 \%$ levels, respectively.

\begin{tabular}{lcccccc}
\hline & \multicolumn{3}{c}{$\begin{array}{c}\text { Pre-AFC (January 1978 to } \\
\text { March 1997) }\end{array}$} & \multicolumn{3}{c}{ Post-AFC (July 1998 to } \\
& \multicolumn{2}{c}{ July 2018) } \\
\hline Exchange Rate & $t$-statistic & TB1 & TB2 & $t$-statistic & TB1 & TB2 \\
\hline IDR/USD & $-7.840^{* *}$ & $1994 \mathrm{M} 03$ & $2016 \mathrm{M} 07$ & -1.528 & $1999 \mathrm{M} 06$ & $2002 \mathrm{M} 05$ \\
IDR/AUD & $-5.729^{* *}$ & $1980 \mathrm{M} 01$ & $1982 \mathrm{M} 01$ & -0.123 & $1999 \mathrm{M} 06$ & $2004 \mathrm{M} 06$ \\
IDR/CNY & $-15.727^{* *}$ & $2002 \mathrm{M} 04$ & $2010 \mathrm{M} 06$ & -2.802 & $2013 \mathrm{M} 07$ & $2014 \mathrm{M} 07$ \\
IDR/EUR & $-10.284^{* *}$ & $1988 \mathrm{M} 02$ & $1995 \mathrm{M} 08$ & $-6.764^{* *}$ & $2003 \mathrm{M} 06$ & $2009 \mathrm{M} 07$ \\
IDR/INR & $-12.363^{* *}$ & $1988 \mathrm{M} 02$ & $2006 \mathrm{M} 05$ & -0.196 & $2009 \mathrm{M} 07$ & $2009 \mathrm{M} 07$ \\
IDR/JPY & $-7.136^{* *}$ & $1994 \mathrm{M} 03$ & $1995 \mathrm{M} 08$ & $-5.497^{* *}$ & $1999 \mathrm{M} 06$ & $2008 \mathrm{M} 07$ \\
IDR/KRW & $-8.564^{* *}$ & $1988 \mathrm{M} 02$ & $1990 \mathrm{M} 02$ & $-3.826^{*}$ & $1999 \mathrm{M} 06$ & $2008 \mathrm{M} 07$ \\
IDR/MYD & -0.120 & $1982 \mathrm{M} 01$ & $1992 \mathrm{M} 03$ & $-4.204^{*}$ & $1999 \mathrm{M} 06$ & $2015 \mathrm{M} 07$ \\
IDR/PKR & $-8.318^{* *}$ & $1980 \mathrm{M} 01$ & $2010 \mathrm{M} 06$ & -3.023 & $1999 \mathrm{M} 06$ & $2013 \mathrm{M} 07$ \\
IDR/PHP & $-3.835^{*}$ & $1988 \mathrm{M} 02$ & $1995 \mathrm{M} 08$ & $-3.783^{*}$ & $1999 \mathrm{M} 06$ & $2004 \mathrm{M} 06$ \\
IDR/SGD & 0 & $1994 \mathrm{M} 03$ & $2002 \mathrm{M} 04$ & $-4.929^{* *}$ & $2013 \mathrm{M} 07$ & $2014 \mathrm{M} 07$ \\
IDR/TWD & $-10.53^{* *}$ & $1985 \mathrm{M} 10$ & $1988 \mathrm{M} 02$ & -3.248 & $2013 \mathrm{M} 07$ & $2016 \mathrm{M} 07$ \\
IDR/THB & $-8.816^{* *}$ & $1990 \mathrm{M} 02$ & $2002 \mathrm{M} 04$ & $-7.860^{* *}$ & $2013 \mathrm{M} 07$ & $2017 \mathrm{M} 07$ \\
IDR/VND & $-6.937^{* *}$ & $1984 \mathrm{M} 01$ & $1994 \mathrm{M} 03$ & 0 & $1999 \mathrm{M} 06$ & $2011 \mathrm{M} 07$ \\
\hline
\end{tabular}

As a final analysis, we estimate the half-life associated with the GARCH(1,1) unit root test regression in equation (1). The half-life is a measure of the speed at which the exchange rate converges to equilibrium (Wu, 1996; Taylor, Peel, and Sarno, 2001; Choi, Nelson, and Sul, 2006; Lothian and Taylor, 2008; Chortareas and Kapetanios, 2009). That is, the half-life indicates the time the exchange rate takes to adjust to its mean following a divergence (Choi, Nelson, and Sul, 2006). From equation (1), we seek to compute the half-life as $H(\pi)=\ln (0.5) / \ln (\pi)$ (see also Wu, 1996; Rossi, 2005; Choi, Nelson, and Sul, 2006). If the estimated value of $H(\pi)$ is higher, then exchange rates take longer to revert to their means. Table 8 shows the half-life estimates. The results show that it takes between 0.4 and 1.1 months for the bilateral exchange rates to revert to their means. Specifically, 10 of the 14 exchange rates $(71 \%)$ have half-lives of less than one month. Therefore, although there is evidence of deviation from equilibrium, the speed of adjustment is quite fast. 
Table 8.

Half-Life Estimates

The table shows the results based on the FX rate model in Equation (1). We report the estimates of $\pi$ (i.e. $\widehat{\pi}$ ) and the half-life, $H(\widehat{\pi})=\ln (0.5) / \ln (\widehat{\pi})$. The half-life estimates are reported in monthly terms. In all cases, the exchange rates are in natural logarithm. The sample period is from January 1978 to July 2018.

\begin{tabular}{lcc}
\hline Exchange Rate & $\widehat{\pi}$ & $\mathbf{H}(\hat{\pi})$ \\
\hline IDR/USD & 0.518 & 1.054 \\
IDR/AUD & 0.426 & 0.812 \\
IDR/CNY & 0.567 & 0.66 \\
IDR/EUR & 0.26 & 0.515 \\
IDR/INR & 0.299 & 0.574 \\
IDR/JPY & 0.327 & 0.62 \\
IDR/KRW & 0.346 & 0.653 \\
IDR/MYD & 0.516 & 1.048 \\
IDR/PKR & 0.38 & 0.716 \\
IDR/PHP & 0.329 & 0.624 \\
IDR/SGD & 0.175 & 0.398 \\
IDR/TWD & 0.518 & 1.054 \\
IDR/THB & 0.53 & 1.092 \\
IDR/VND & 0.274 & 0.535 \\
\hline
\end{tabular}

\section{CONCLUSION}

This paper examines whether the FX market in Indonesia is efficient. The relevance of this empirical exploit lies in the fact that a rejection of the FX market efficiency means investors and/or traders can extract profit by exploiting pricing anomalies and that policies pursued under the assumption of an efficient market could be ineffective. From a policy perspective, this would require interventions by the relevant authorities to correct the market mispricing. The empirical literature remains inconclusive. More so, unit root-based tests generally treat structural breaks as exogenous or the underlying errors of the test regression as i.i.d. Our solution to these limitations is to testing FX market efficiency using a GARCH model-based test for unit roots. This approach deals with both endogenous structural breaks and heteroskedasticity.

We first show that the exchange rates of Indonesia exhibit up to two structural breaks. Then, we show that the error terms associated with the exchange rate models are far from i.i.d. From two tests for unit roots that incorporate structural breaks but not heteroskedasticity, we find that the EMH is rejected for approximately $29 \%$ of the exchange rates. We explore the hypothesis further by accounting for both structural breaks and heteroskedasticity. We find that the rejection rate is quite a bit higher $(50 \%)$. As a robustness test, we use daily data and reapply the procedure. We find the results to be generally robust. Further, we divide the sample into preand post-AFC periods and find that the FX market was less efficient before the crisis. Finally, we estimate half-lives and find that $71 \%$ of the exchange rates adjust 
to their means within one month, likely implying that the market is efficient in the short term.

The main implications are that the Indonesian FX market is still inefficient in a small number of currencies and FX investors could derive profits from such exchange rates. Because the FX market seems to only be efficient in the short term, investors might be able to derive profits by employing a buy-and-hold strategy. Although the FX market has become relatively more efficient in the aftermath of the AFC, there is room for policy initiatives. Authorities could pursue the greater transparency of FX transactions to limit potential manipulation.

\section{REFERENCES}

Al-Khazali, O. M., Pyun, C. S., \& Kim, D. (2012). Are Exchange Rate Movements Predictable in Asia-Pacific Markets? Evidence of Random Walk and Martingale Difference Processes. International Review of Economics \& Finance, 21, 221-231.

Alexander, C., \& Lazar, E. (2006). Normal Mixture GARCH (1, 1): Applications to Exchange Rate Modelling. Journal of Applied Econometrics, 21, 307-336.

Bai, J., \& Perron, P. (1998). Estimating and Testing Linear Models with Multiple Structural Changes. Econometrica, 66, 47-78.

Bai, J., \& Perron, P. (2003). Computation and Analysis of Multiple Structural Change Models. Journal of Applied Econometrics, 18, 1-22.

Balvers, R., Wu, Y., \& Gilliland, E. (2000). Mean Reversion Across National Stock Markets and Parametric Contrarian Investment Strategies. The Journal of Finance, 55, 745-772.

Basu, S. (1977). Investment Performance of Common Stocks in Relation to Their Price-Earnings Ratios: A test of the Efficient Markets Hypothesis. Journal of Finance, 32, 663-682.

Belaire-Franch, J., \& Opong, K. K. (2005). Some Evidence of Random Walk Behavior of Euro Exchange Rates Using Ranks and Signs. Journal of Banking E Finance, $29,1631-1643$.

Bollerslev, T. (1990). Modelling the Coherence in Short-Run Nominal Exchange Rates: A Multivariate Generalized ARCH Model. The Review of Economics and Statistics, 498-505.

Caner, M., and Hansen, B. E. (2001). Threshold Autoregression With a Unit Root, Econometrica, 69, 1555-1596.

Cerra, V., \& Saxena, S. C. (2002). Contagion, Monsoons, and Domestic Turmoil in Indonesia's Currency Crisis. Review of International Economics, 10, 36-44.

Charles, A., Darné, O., \& Kim, J. H. (2012). Exchange-Rate Return Predictability and the Adaptive Markets Hypothesis: Evidence from Major Foreign Exchange Rates. Journal of International Money and Finance, 31, 1607-1626.

Chaudhuri, K., \& Wu, Y. (2003). Random Walk Versus Breaking Trend in Stock Prices: Evidence from Emerging Markets. Journal of Banking E Finance, 27, 575592.

Chiang, S. M., Lee, Y. H., Su, H. M., \& Tzou, Y. P. (2010). Efficiency Tests of Foreign Exchange Markets for Four Asian Countries. Research in International Business and Finance, 24, 284-294. 
Choi, I. (1999). Testing the Random Walk Hypothesis for Real Exchange Rates. Journal of Applied Econometrics, 14, 293-308.

Choi, C-Y., Nelson C. M., and Sul, D. (2006). Unbiased Estimation of the Half-Life to PPP Convergence in Panel Data. Journal of Money, Credit and Banking, 38, 921-938.

Chortareas, G., and Kapetanios, G. (2009). Getting PPP Right: Identifying MeanReverting Real Exchange Rates in Panels. Journal of Banking E Finance, 33, 390404.

Chow, K. V., \& Denning, K. C. (1993). A Simple Multiple Variance Ratio Test. Journal of Econometrics, 58, 385-401.

Daniel, K., \& Titman, S. (1999). Market Efficiency in an Irrational World. Financial Analysts Journal, 55, 28-40.

De Bondt, W. F., \& Thaler, R. (1985). Does the Stock Market Overreact? The Journal of Finance, 40, 793-805.

Enoch, C., Frécaut, O., \& Kovanen, A. (2003). Indonesia's Banking Crisis: What Happened and What did We Learn? Bulletin of Indonesian Economic Studies, 39, 75-92.

Fama, E. F. (1965). The Behavior of Stock-Market Prices. The Journal of Business, 38, 34-105.

Fama, E. F. (1970). Efficient Capital Markets: A Review of Theory and Empirical Work. The Journal of Finance, 25, 383-417.

Fama, E. F., Fisher, L., Jensen, M. C., \& Roll, R. (1969). The Adjustment of Stock Prices to New Information. International Economic Review, 10, 1-21.

Fama, E. and French, K. (1992). The Cross-Section of Expected Stock Returns. Journal of Finance, 47, 427-465.

Fama, E. F., \& French, K. R. (2012). Size, Value, and Momentum in International Stock Returns. Journal of Financial Economics, 105, 457-472.

Giannellis, N., \& Papadopoulos, A. P. (2009). Testing for Efficiency in Selected Developing Foreign Exchange Markets: An Equilibrium-Based Approach. Economic Modelling, 26, 155-166.

Goldstein, M. (1998). The Asian Financial Crisis: Causes, Cures, and Systemic Implications (Vol. 55). Peterson Institute.

Gospodinov, N. (2008). Asymptotic and Bootstrap Tests for Linearity in a TARGARCH $(1,1)$ Model with a Unit Root. Journal of Econometrics, 146, 146-161.

Hall, A. (1994). Testing for a Unit Root in Time Series with Pretest Data-Based Model Selection. Journal of Business \& Economic Statistics, 12, 461-470.

Harris, R. D., \& Yilmaz, F. (2009). A Momentum Trading Strategy Based on the Low Frequency Component of the Exchange Rate. Journal of Banking E Finance, 33, 1575-1585.

Ilzetzki, E., Reinhart, C. M., \& Rogoff, K. S. (2017). Exchange Arrangements Entering The 21 ${ }^{\text {st }}$ Century: Which Anchor Will Hold? National Bureau of Economic Research (No. w23134).

Iyke, B. N. (2017). Real Exchange Rates Persistence in the West African Monetary Zone: A Revisit of the PPP Puzzle. International Journal of Emerging Markets, 12, 366-383.

Jegadeesh, N., \& Titman, S. (2001). Profitability of Momentum Strategies: An Evaluation of Alternative Explanations. The Journal of Finance, 56, 699-720. 
Jovanovic, F. (2012). Bachelier: Not the Forgotten Forerunner He Has Been Depicted as. An analysis of the Dissemination of Louis Bachelier's Work in Economics. The European Journal of the History of Economic Thought, 19, 431-451.

Katusiime, L., Shamsuddin, A., \& Agbola, F. W. (2015). Foreign Exchange Market Efficiency and Profitability of Trading Rules: Evidence from a Developing Country. International Review of Economics \& Finance, 35, 315-332.

Kim, J. H. (2006). Wild Bootstrapping Variance Ratio Tests. Economics letters, 92, 38-43.

Kim, J. H. (2009). Automatic Variance Ratio Test Under Conditional Heteroskedasticity. Finance Research Letters, 6, 179-185.

Kim, K., \& Schmidt, P. (1993). Unit Root Tests with Conditional Heteroskedasticity. Journal of Econometrics, 59, 287-300.

Lee, J., \& Strazicich, M. C. (2003). Minimum Lagrange Multiplier Unit Root Test with Two Structural Breaks. Review of Economics and Statistics, 85, 1082-1089.

Lim, K. P., \& Brooks, R. (2011). The Evolution of Stock Market Efficiency Over Time: A Survey of the Empirical Literature. Journal of Economic Surveys, 25, 69-108.

Ling, S., \& Li, W. K. (2003). Asymptotic Inference for Unit Root Processes with GARCH $(1,1)$ Errors. Econometric Theory, 19, 541-564.

Ling, S., Li, W. K., \& McAleer, M. (2003). Estimation and Testing for Unit Root Processes with GARCH $(1,1)$ Errors: Theory and Monte Carlo Evidence. Econometric Reviews, 22, 179-202.

Lo, A.W. (2004). The Adaptive Markets Hypothesis: Market Efficiency from an Evolutionary Perspective. The Journal of Portfolio Management, 30, 15-29.

Lo, A. W., \& MacKinlay, A. C. (1988). Stock Market Prices do not Follow Random Walks: Evidence from a Simple Specification Test. The Review of Financial Studies, 1, 41-66.

Lothian, J. R., and Taylor, M. P. (2008). Real Exchange Rates Over The Past Two Centuries: How Important is the Harrod-Balassa-Samuelson Effect? The Economic Journal, 118, 1742-1763.

Lumsdaine, R. L., \& Papell, D. H. (1997). Multiple Trend Breaks and the Unit-Root Hypothesis. Review of Economics and Statistics, 79, 212-218.

Malkiel, B. G. (2003). The Efficient Market Hypothesis and Its Critics. Journal of Economic Perspectives, 17, 59-82.

Narayan, P. K., Liu, R., \& Westerlund, J. (2016). A GARCH Model for Testing Market Efficiency. Journal of International Financial Markets, Institutions and Money, 41, 121-138.

Narayan, P. K., \& Popp, S. (2010). A New Unit Root Test with Two Structural Breaks in Level and Slope at Unknown Time. Journal of Applied Statistics, 37, 1425-1438.

Neely, C. J., Weller, P. A., \& Ulrich, J. M. (2009). The Adaptive Markets Hypothesis: Evidence from the Foreign Exchange Market. Journal of Financial and Quantitative Analysis, 44, 467-488.

Nelson, C. R., \& Plosser, C. R. (1982). Trends and Random Walks in Macroeconmic Time Series: Some Evidence and Implications. Journal of Monetary Economics, 10, 139-162. 
Olson, D. (2004). Have Trading Rule Profits in the Currency Markets Declined Over Time? Journal of Banking \& Finance, 28, 85-105.

Park, C. H., \& Irwin, S. H. (2007). What Do We Know About the Profitability of Technical Analysis? Journal of Economic Surveys, 21, 786-826.

Perron, P. (1989). The Great Crash, the Oil Price Shock, and the Unit Root Hypothesis. Econometrica, 57, 1361-1401.

Perron, P., \& Vogelsang, T. J. (1992). Testing for a Unit Root in a Time Series with a Changing Mean: Corrections and Extensions. Journal of Business E Economic Statistics, 10, 467-470.

Rapach, D. E., \& Strauss, J. K. (2008). Structural Breaks and GARCH Models of Exchange Rate Volatility. Journal of Applied Econometrics, 23, 65-90.

Reinhart, C. M., and Rogoff, K. S. (2004). The Modern History of Exchange Rate Arrangements: A Reinterpretation. Quarterly Journal of Economics, 119, 1-48.

Richardson, M., \& Smith, T. (1991). Tests of Financial Models in the Presence of Overlapping Observations. The Review of Financial Studies, 4, 227-254.

Rosenberg, B., Reid, K., and Lanstein R. (1985). Persuasive Evidence of Market Inefficiency. Journal of Portfolio Management, 13, 9-17.

Rossi, B. (2005). Confidence Intervals for Half-Life Deviations from Purchasing Power Parity. Journal of Business E Economic Statistics, 23, 432-442.

Samuelson, P. A. (1965). Proof that Properly Anticipated Prices Fluctuate Randomly. Industrial Management Review, 6, 41-49.

Seo, B. (1999). Distribution Theory for Unit Root Tests with Conditional Heteroskedasticity. Journal of Econometrics, 91, 113-144.

Serban, A. F. (2010). Combining Mean Reversion and Momentum Trading Strategies in Foreign Exchange Markets. Journal of Banking \& Finance, 34, 27202727.

Shiller, R. J. (2003). From Efficient Markets Theory to Behavioral Finance. Journal of Economic Perspectives, 17, 83-104.

Tan, W. (2018). Indonesia's Rupiah Falls to Its Weakest Level in more than 20 Years. Retrieved from indonesia-rupiah-falls-to-weakest-level-in-more-than20-years.html.

Taylor, M. P., Peel, D. A., and Sarno, L. (2001). Nonlinear Mean-Reversion in Real Exchange Rates: Toward a Solution to the Purchasing Power Parity Puzzles. International Economic Review, 42, 1015-1042.

Timmermann, A., \& Granger, C. W. (2004). Efficient Market Hypothesis and Forecasting. International Journal of Forecasting, 20, 15-27.

Westerfield, J. M. (1977). An Examination of Foreign Exchange Risk Under Fixed and Floating Rate Regimes. Journal of International Economics, 7, 181-200.

Wright, J. H. (2000). Alternative Variance-Ratio Tests Using Ranks and Signs. Journal of Business E Economic Statistics, 18, 1-9.

Wu, Y. (1996). Are Real Exchange Rates Non stationary? Evidence from a PanelData Test. Journal of Money, Credit and Banking, 28, 54-63.

Yamazawa, I. (1998). The Asian Economic Crisis and Japan. The Developing Economies, 36, 332-351.

Zivot, E., \& Andrews, D. W. K. (2002). Further Evidence on the Great Crash, the Oil-Price Shock, and the Unit-Root Hypothesis. Journal of Business E Economic Statistics, 20, 25-44. 
This page is intentionally left blank 